\title{
Streptobacillary rat-bite fever
}

INSERM

\section{Source}

INSERM. (1999). Orphanet: an online rare disease and orphan drug data base.

Streptobacillary rat-bite fever. ORPHA:99905

Streptobacillary rat-bite fever (RBF) is a systemic zoonosis caused by the aerobic Gramnegative bacterium Streptobacillus moniliformis and is transmitted to humans through the bites and scratches of infected rats. 